\section{Books Received}

Bibliography of Latvian Publications Published Outside Latvia, 1955. Ed. by Dr. phil. Benjamins Jēgers, Mag. hist. Vitauts Kalnins, Magdalēne Rozentale, M.S. Washington, D. C.: American Latvian Association in the United States, Inc., Foundation for Latvian Culture, 1957. 63p. $\$ 1.50$.

California State Publications, a Manual for Their Acquisition, Processing, and Use. By Members of the Documents Committee of the California Library Association. Sacramento: California Department of Finance, 1957. $125 \mathrm{p}$.

Fund Og Forskning, I Det Kongelige Biblioteks Samlinger, IV, 1957. Kobenhavn: Udgivet Af Det Kongelige Bibliotek, 1957. 148p.

Index to Philippine Periodicals, First Annual Cumulation, October 1955-September 1956. Ed. by Maxima M. Ferrer. Manila: Inter-De- partmental Reference Service, Institute of Public Administration, University of the Philippines, 1956. 459p.

Polish Periodicals 1953-1956, An Annotated Bibliography. By Jan Wepsiec. Washington, D. C.: The Catholic University of America Press, 1957. 169 p. $\$ 3.50$.

Select List of Standard British Scientific and Technical Books. Ed. by L. J. Anthony, F.L.A. Atomic Energy Research Establishment, Harwell. Comp. at the request of the British Council. London: Aslib, 1957. 88p.

Union List of Microfilms, Revised, Enlarged and Cumulated Edition, Supplement 19521955. Philadelphia Bibliographical Center and Union Library Catalogue. Ann Arbor, Michigan: J. W. Edward, 1957. 1019p. \$11.00.

Using Library Resources in Educational Research. By Ruth E. Seeger. Bureau of Educational Research, Ohio State University. Columbus: The University Press, 1957. 26p.

\title{
Classified Advertisements
}

Rate: \$1 per line; 3-line minimum. Closes first of month preceding date of issue.

\section{OUT-OF-PRINT BOOKS}

BARNES \& NOBLE, INC. supplies books not obtainable from publishers immediately from stock of over a million volumes or in reasonably quick time through free Search Service. Send lists to Dept. CR, Barnes \& Noble, Inc., 105 Fifth Ave., New York 3, N. Y.

CATALOGER. Starting salary $\$ 4,000$. Month's vacation. Usual benefits. Faculty status. Write Librarian, Springfield College, Springfield 9, Mass.

STANLEY GILMAN, American History, Newspaper History and Out of Print Books. Box 131, Cooper Station, New York 3, N. Y.

IRREGULAR SERIALS is one of our specialties. Foreign books and periodicals, current and out of print. Albert J. Phiebig, Box 352, White Plains, N. Y.

WE ARE LOOKING FOR TWO topnotch librarians who want challenging positions offering a real future: one to supervise ordering, cataloging, and processing, the other to direct an ambitious program in the field of audio-visual materials. Salary for both, $\$ 5,046-\$ 5,916$, three weeks vacation, sick leave, retirement, and other benefits. Rapidly expanding library system in pro- gressive community which offers the best in Southern California living. Looking forward to new central library building and additional branches. Apply Raymond M. Holt, Librarian, Pomona Public Library, 380 North Main Street, Pomona, California.

\section{ASSISTANT LIBRARIAN \\ CHEMICAL ABSTRACTS SERVICE}

To assume complete charge of a world-wide chemical literature selection and procurement program plus administrative duties. Training or experience in chemical literature with facility in languages. Open salary. E. J. Crane, Director and Editor, Chemical Abstracts Service, Ohio State University, Columbus 10, Ohio.

POSITION as Assistant Librarian-Medical Library of 80,000 volumes, in Baltimore. Cataloging and varied duties. Salary depending on qualifications. Forty-hour week, no night work. Box 230, ACRL, 50 East Huron St., Chicago 11, Ill.

EMORY UNIVERSITY LIBRARY is seeking head circulation librarian, upper age limit 35 , experience in public services, application with photograph, starting salary $\$ 5,500$. Apply Guy R. Lyle, Emory University, Georgia. 